Undas Vol 12. , Nomor 1, Juni 2016 : 49--60

\title{
PANTANGAN DALAM PEMBUKAAN LAHAN PERTANIAN MASYARAKAT DAYAK HALONG
}

\author{
Various Kinds of Prohibitions in Land Clearing of Dayak Halong Society
}

\author{
Saefuddin \\ Balai Bahasa Kalimantan Selatan \\ Jalan Jenderal Ahmad Yani Km 32,2, Loktabat, Banjarbaru 70712 Kalimantan Selatan \\ Telepon (0511) 4772641, Pos-el: kangasef@yahoo.co.id
}

\begin{abstract}
Abstrak: Pantangan merupakan bentuk kearifan lokal dalam suatu masyarakat tradisional. Pantangan erat kaitannya dengan kepercayaan yang berlangsung di dalam masyarakat. Sebagian masyarakat di daerah memiliki pantangan yang satu sama lainnya memiliki kesamaan dan perbedaan. Keragamaan itu merupakan ciri daerah masing-masing, termasuk pantangan yang terdapat dalam masyarakat Dayak Halong di antaranya ketika mereka menerapkan tatacara pembukaan lahan pertanian. Hal-hal yang melingkupi tatacara itu semua, mereka taati bersama dalam aturan adat atau disebut pantangan. Berdasarkan uraian itu, masalah dalam penelitian ini apakah pantangan masih terdapat dalam masyarakat adat Dayak Halong sebagai masyarakat yang masih mempertahankan adat sebagai bentuk kearifan lokal yang berlangsung dalam masyarakat tersebut. Metode yang digunakan dalam penelitian ini ialah metode deskriptifkualitatif. Metode deskriptif ialah suatu metode untuk memperoleh informasi mengenai adat pantangan sebagai bentuk kearifan lokal yang berlangsung dalam masyarakat setempat. Hasil penelitian ini akan memperoleh gambaran tentang jenis kearifan lokal mengenai pantangan dalam bidang pertanian dalam masyarakat Dayak Halong di Kabupaten Balangan.
\end{abstract}

Kata kunci: Pantangan, lahan pertanian, dan Dayak Halong

\begin{abstract}
Various kinds of prohibitions is one of local wisdom in traditional society. It has close relation with myth that happens in the society. Some local people have various kinds of prohibitions; it can be same or different one to another. That variation is the characteristic of each place including various kinds of prohibitions that live in the society, one of them is Dayak Halong when they apply the customs and manners of land clearing. All those customs and manners are obeyed by all people in the form of tradition arrangement or they call it various kinds of prohibitions. Base on the explanation above the problem in this study is whether various kind of prohibitions is still live in the tradition of Dayak Halong society as the form of local wisdom that happens in that society. This study uses descriptive qualitative method. Descriptive method is a method to get information about the conservation of various kinds of prohibitions as a form of local wisdom that lives in the society. This study will get a description of local wisdom about various kinds of prohibitions in the farm in Dayak Halong society at Balangan Regency.
\end{abstract}

Key words: Various kind of prohibitions, land clearing, Dayak Halong.

\section{PENDAHULUAN}

Pantangan merupakan salah satu dari kearifan lokal dalam sebuah masyarakat yang tidak tertulis. Pantangan ini berisi berbagai larangan perbuatan dan nasihat yang harus dihindari oleh masyarakat dalam kehidupan sehari-hari. Pelarangan ini berkaitan erat 
dengan hal-hal yang bersifat mistik dan diyakini dapat terjadi pada siapa saja yang melanggar aturan tersebut. Pantangan merupakan khasanah kebudayaan yang memiliki keunikan dan kekhasan tersendiri. Hal inilah yang membuat pantangan di satu daerah dengan daerah lain atau antara satu suku dengan suku lain memiliki perbedaan atau keunikan tersendiri. Sebagai satu di antara produk kebudayaan, pantangan menjadi satu di antara unsur yang melekat dengan masyarakat. Hampir di semua daerah atau suku memiliki pantangan atau disebut juga pantangan (Stepanus, 2005:20)

Satu di antara tradisi lisan dan budaya yang lahir dan tumbuh subur di lingkungan masyarakat, membuat pantangan tidak hanya sekadar menjadi pantangan yang begitu saja, tetapi jauh dari itu sesungguhnya pantangan memiliki makna yang amat mendalam bagi masyarakat adat. Ancaman seperti malapetaka, bencana atau kecelakaan tentu tidak lebih dari sebuah sarana atau strategi untuk memperkuat larangan yang ada dalam setiap pantangan. Selain itu pula, ancaman yang terkesan menakut-nakuti ini juga berfungsi sebagai strategi komunikasi, sebab pada umumnya manusia lebih mudah dilarang untuk tidak melakukan sesuatu jika ditakuti terlebih dahulu. Hal ini dikerenakan bahwa tidak ada satu pun orang yang ingin hidupnya celaka atau kurang beruntung.

Pantangan merupakan suatu kebiasaan masyarakat dalam hal menghindari masalah dan memberikan nasihat kepada anaknya atau masyarakat lain. Degan kata lain, pantangan juga dapat diartikan sebagai suatu tradisi atau budaya lisan yang diungkapkan atau disampaikan oleh orang tua terhadap anakanaknya atau terhadap sesama anggota masyarakat dengan maksud memberi peringatan, teguran, ajaran, dan nasihat. Hal ini sejalan dengan pendapat Ibrahim (2012:4) yang mengatakan bahwa pantangan merupakan satu bentuk strategi komunikasi orang tua dalam memberikan bimbingan dan tuntunan hidup pada generasi mudanya.

Pantangan berkaitan erat dengan mitos, di mana di dalam mitos tersebut terkandung unsur sistem kepercayaan di dalam masyarakat. Sebagai suatu sistem, kepercayaan memiliki otoritas mengatur bagaimana manusia harus berpendapat, menentukan bagaimana manusia berinteraksi dengan setiap aspek kehidupan di luar diri manusia. Sistem kepercayaan sendiri tersimpan jauh di dalam pikiran bawah sadar, memberikan informasi apa yang baik dan buruk, apa yang benar dan salah (Sisva, 2015:48).

Pantangan dapat pula memberikan efek rasa takut seperti malapetaka, bencana atau kecelakaan tentu tidak lebih dari sebuah sarana atau strategi untuk memperkuat larangan yang ada dalam setiap pantangan. Hal ini sejalan dengan pendapat Ibrahim (2011: 28), menakutkan dengan ancaman petaka dan bencana apabila melakukan sesuatu yang dipantang dan dilarang sebenarnya hanya untuk sarana dan strategi komunikasi. Sebab pada umumnya manusia lebih mudah dilarang melakukan sesuatu dengan cara ditakuti terlebih dahulu.

Berbicara masalah pantangan, tidak bisa terlepas dari makna pantangan tersebut. Semua pantangan yang ada dalam masyarakat pasti memiliki makna atau pesan yang hendak disampaikan. Memang agak sulit jika dikaitkan antara teks pantangan dengan ancaman atau akibat jika melanggar pantangan tersebut. Oleh karena itu, sebagian orang berpendapat bahwa teks pantangan tersebut hanya untuk menakut-nakuti atau mengancam saja, bukanlah makna yang sesungguhnya.

Menurut pendapat Ibrahim (2012-: 93) bahwa semua pantangan yang ada dalam 
masyarakat Melayu memiliki makna tekstual dan makna terdalam. Makna terkstual (makna tersurat) ialah makna yang terkandung dalam teks pantangan yang dapat dimaknai oleh masyarakat sebagai sebuah larangan yang hanya untuk menakut-nakuti. Dengan kata lain bahwa makna tekstual dapat dikatakan akibat dari melanggar pantangan. Selain itu, pantangan juga memiliki makna terdalam (makna tersirat) ialah makna yang diperoleh pembaca setelah pembaca tersebut memaknai secara mendalam teks pantangan dengan mempertimbangkan unsur maksud dan tujuan orang tua menyampaikan pantangan tersebut.

\section{KERANGKA TEORI}

Pantangan merupakan satu tradisi yang hidup dalam masyarakat. Pantangan ini pada dasarnya memunyai tujuan dan maksud tertentu terutama dalam menyangkut upaya pemeliharaan keseimbangan dan kelestarian hidup dan relasi sosial dengan alam (Ibrahim, 2012; 12). Pantangan yang hidup dalam masyarakat berhubungan erat dengan mitosmitos yang berkembang dalam masyarakat tersebut.

Menurut Kamus Besar Bahasa Indonesia (KBBI, 2013: 114), mitos ialah cerita suatu bangsa tentang dewa dan pahlawan zaman dahulu, mengandung penafsiran tentang asalusul semesta alam, manusia, dan bangsa tersebut, mengandung arti mendalam yang diungkapkan dengan cara gaib. Definisi ini selaras dengan kenyataan yang ada dimana mitos yang berkembang lebih banyak terkait dengan asal-usul alam semesta, manusia bahkan cikal bakal suatu kelompok/ suku bangsa tertentu seperti yang diuraikan di atas.

Mitos juga didefinisikan sebagai sistem kepercayaan dari suatu kelompok manusia, yang berdiri atas sebuah landasan yang menjelaskan cerita-cerita yang suci yang berhubungan dengan masa lalu. Mitos yang dalam arti asli sebagai kiasan dari zaman purba merupakan cerita yang asal usulnya sudah dilupakan, tetapi ternyata pada zaman sekarang mitos dianggap sebagai suatu cerita yang dianggap benar. Mitos biasanya berisi wahyu tentang kenyataan yang bersifat supranatural, yang memunyai realitas, seperti mitos kosmogami, adanya dewa dan kekuatan yang gaib. Mitos bagi masyarakat pendukungnya bukanlah sekadar cerita yang menarik atau dianggap bersejarah, akan tetapi merupakan satu pernyataan dan kebenaran yang tinggi, atau kenyataan yang utama yang memberikan pola dan landasan bagi kehidupan dewasa ini (Harsojo, 1988:228).

Seperti uraian di atas, mitos apakah itu kiasan atau bukan di masa lalu, tetapi kenyataannya saat ini mitos masih dianggap sebagai cerita yang diyakini kebenarannya. Oleh karena diyakini kebenarannya, termasuk kebenaran adanya sanksi jika dilanggar, maka mitos masih dijadikan sebagai pedoman hidup manusia pada saat ini.

Definisi lain diungkapkan oleh C.A Van Peursen (1992:28) yang mendefinisikan mitos sebagai sebuah cerita yang memberikan pedoman dan arah tertentu kepada sekelompok orang. Lebih lanjut, Van Peursen menjelaskan bahwa mitos memberikan arah kepada kelakuan manusiawi dan merupakan pedoman untuk kebijaksanaan manusia. Lewat mitos, manusia dapat turut serta mengambil bagian dalam kejadian disekitarnya, dapat menanggapi daya-daya kekuatan di sekitarnya. Definisi ini mengandung arti bahwa di dalam mitos, keberadaan kekuatan lain daya, di luar manusia memang ada di alam sekitar hidup manusia.

Menurut Bascom yang dikutip Danandjaya (1991:50), mite atau mitos ialah cerita prosa rakyat yang dianggap benar- 
benar terjadi serta dianggap suci oleh yang empunya cerita. Mite ditokohkan oleh para dewa atau makhluk setengah dewa. Peristiwa terjadi di dunia lain atau di dunia yang bukan seperti yang dikenal sekarang, dan terjadi pada masa lampau. Mitos merupakan kepercayaan berkenaan kejadian dewa-dewa dan alam seluruhnya. Mitos juga merujuk kepada satu cerita dalam sebuah kebudayaan yang dianggap memunyai kebenaran mengenai suatu peristiwa yang pernah terjadi pada masa dahulu. Ia dianggap sebagai suatu kepercayaan dan kebenaran mutlak yang dijadikan sebagai rujukan, atau merupakan suatu dogma yang dianggap suci dan memunyai konotasi upacara.

Dari beberapa definisi di atas, terdapat beberapa unsur yang terkandung dalam mitos yaitu sebagai berikut. 1) mitos merupakan cerita yang terjadi dimasa lalu dan dianggap suci oleh yang memiliki cerita tersebut, 2) dalam mitos terkandung kekuatan gaib, kekuatan lain di luar manusia, dunia supranatural atau dunia lain, 3) mitos merupakan sistem kepercayaan sekelompok manusia yang dijadikan pedoman bagi masyarakat pendukungnya, 4) mitos memunyai kebenaran tertinggi dan kepercayaan mutlak yang dijadikan rujukan dalam kehidupan dewasa ini.

Dalam kehidupan manusia, eksistensi mitos tergantung dari bagaimana masyarakat pendukungnya memperlakukan mitos. Sebagai representasi dari sistem percayaan, keyakinan akan kebenaran mitos menjadi faktor utama. Seperti yang diungkapkan Gale (Belief System, in Workd of Sociology) yang dikutip oleh Liliweri (2014:14), sebuah sistem kepercayaan dari kelompok tertentu selalu ditandai dengan keyakinan yang diterima oleh individu dalam kelompok itu. Tanpa adanya keyakinan, mitos akan terancam keberadaannya. Senada dengan hal itu, Cassirer
(1990:22) juga menyatakan bahwa dalam mitos, imajinasi mistis selalu melibatkan tindakan percaya. Tanpa kepercayaan bahwa objeknya nyata, maka mitos kehilangan dasardasarnya. Keyakinan dan kepercayaan inilah yang tetap menjaga mitos sebagai bagian dari kehidupan masyarakat. Keyakinan individu dan keyakinan kolektif itu sendiri terwujud apabila ada regenerasi atau adanya upaya pewarisan mitos oleh masyarakat pendukungnya.

Regenerasi bisa dilakukan melalui tuturan/oral atau dalam bentuk suatu kegiatan. Menurut Van Peursen, mitos dapat dituturkan dan dapat juga diungkapkan dalam tari atau pementasan wayang. Hal paling umum yang bisa ditemui ialah dalam bentuk tuturan/ penceritaan kembali secara langsung kepada generasi selanjutnya bisa melalui cerita, peringatan/pantang-larang atau tersirat dalam ritual tertentu.

Mitos bukan hanya berfungsi sebagai pedoman bagi masyarakat pendukungnya dalam bertindak, tetapi mitos juga memiliki fungsi lain. Van Peursen (1992:52) menyatakan bahwa fungsi mitos, yaitu dapat 1) menyadarkan manusia bahwa ada kekuatankekuatan ajaib. Mitos tidak memberikan informasi kekuatan itu tetapi membantu manusia agar ia bisa menghayati daya itu sebagian kekuatan yang bisa memengaruhi dan menguasai alam dan kehidupan. Dalam sebuah upacara, alam bersatu dengan alam atas/dunia gaib. Oleh karena itu ada pemisahan antara dunia sakral/angker dan profan dan 2) mitos dapat memberikan jaminan masa kini, misalnya dongeng masa lalu yang diceritakan melalui tarian. Peragaan ini seolah-olah menghadirkan kembali suatu peristiwa yang pernah terjadi dengan demikian dijamin keberhasilan usaha serupa dewasa, sebagai contoh: pada musim tanam, 
siang malam dinyanyikan atau didongengkan cerita yang bertalian dengan tema kesuburan.

Mitos juga bisa berfungsi sebagai pengatur tingkah laku. Mitos bisa menjadi pembatas tingkah laku/fungsi kontrol (dimana anggota masyarakat saling mengingatkan satu sama lain untuk bertindak sesuai dengan mitos yang berlaku, Laksono dkk (2000:14) menyatakan bahwa dalam kehidupan masyarakat tradisional keberadaan mitos berfungsi untuk mengukuhkan sesuatu yang bernilai sosial. Mitos merupakan kontrol bagi aktivitas masyarakat. Rasa keberanian dan ketakutan seringkali dipengaruhi oleh adanya mitos. Dengan kata lain mitos tak ubahnya peraturan tak tertulis yang mengatur kehidupan masyarakat.

\section{METODE PENELITIAN}

Metode yang digunakan dalam penelitian ini ialah metode deskriptif-kualitatif. Metode ialah suatu prosedur untuk mencapai suatu tujuan yang telah ditetapkan (Semi, 1990: 105). Metode deskriptif, ialah suatu metode untuk memperoleh informasi tentang kondisi yang ada pada suatu penelitian dan melukiskan "apa yang ada itu" (Furchan, 1982: 44).

Metode kualitatif memberi ruang kepada peneliti untuk terlibat langsung dengan objek yang diteliti sebagai pengamat dan pemberi interpretasi. Metode kualitatif mengutamakan kedalaman penghayatan terhadap interaksi antara konsep-konsep yang sedang diteliti. Dengan metode kualitatif ini pantangan yang terdapat dalam masyarakat adat melalui hasil pengamatan dan wawancara terhadap masyarakat adat Dayak Halong, kemudian data itu diinterpretasi dan hasil interpretasi itu menjadi sebuah hasil kajian.

Teknik yang yang dipakai dalam penelitian ialah studi pustaka. Data yang telah dikumpulkan terlebih dahulu dilakukan klasifikasi, verifikasi, interpretasi data, dianalisis sampai pada pembahasan hingga diperoleh kesimpulan sementara atas jawaban-jawaban dari informan terhadap pertanyaan yang berdasarkan pada pedoman wawancara. Analisis menckupi penafsiran semua data pantun yang dikumpulkan, mengatur hasil-hasil penelitian yang sedemikian rupa sehingga menjadi informasi yang jelas tentang pantangan dalam masyarakat Dayak Halong Kabupaten Balangan di Kalimantan Selatan.

Analisis data dalam penelitian kualitatif berlangsung selama proses penelitian, karena setiap informasi yang akan dijadikan materi penulisan harus melalui suatu proses pertimbangan dan di dalamnya mengandung aktivitas analisis. Analisis deskriptif itu akan menguraikan serta menghubungkan antara hasil yang diperoleh dari data dan wawancara mendalam dengan catatan lapangan. Antara apa yang dilihat dan apa yang didengar, diuraikan secara cermat dalam kata-kata sehingga dapat membangun konsep yang lebih bermakna, dalam mengkaji permasalahan penelitian. Selanjutnya, membuat kesimpulan-kesimpulan sebagai hasil analisis permasalahan penelitian. Kesimpulan tersebut diharapkan dapat melahirkan proposisi-proposisi tentang perilaku yang terjadi pada masyarakat yang menjadi objek penelitian.

\section{ANALISIS DAN PEMBAHASAN}

\subsection{Pantangan dalam Bidang Pertanian}

Pantangan dalam bidang pertanian atau hal-hal yang berkaitan dengan 
pembukaan lahan (masyarakat Dayak Halong), yaitu di lingkungan keluarga dan lingkungan masyarakat yang menjaga adat pantangan sebagai bagian dari kesehari-harian masyarakat setempat, pantangan yang dimaksud, ialah sebagai berikut.

\section{1) Pantangan dalam Membuka Lahan}

Bagi orang Dayak mengapa ladang harus berpindah? Tahun pertama namanya lahan yang baru. Tahun kedua namanya ramisan. Tahun ramisan itu, bagi orang tua dahulu mengatakan kalau ada selamatan buanang atau buharing itu kurang sah. Oleh karena itu, mereka harus membuat seborongan lahan baru yang untuk tambinian. Tambinian ini merupakan permulaan melepas padi. Jadi tahun pertama padi yang baru dipanen harus disimpan dan dipisahkan serta dibacakan doa terlebih dahulu. Tahun kedua harus membuka lahan tambahan sedikit/banyak. Mengapa perlu dibuka lahan tambahan karena di arogan dianggap lahan bekas. Lahan arogan merupakan lahan daur ulang karena memanfaatkan lahan lama dan baru.

Tahapan-tahapan membuka lahan sebagai berikut. 1) membakar dupa, kemenyan, dan jerengau. Jerengau sebagai sarana memanggil arwah para leluhur dengan adanya dupa dan kemenyan, 2) membuat perapian terlebih dahulu. Kemudian membakar kemenyan dan dupa, baru mengigit jerengau dan membaca doa memanggil leluhur, 3) pelaporannya dengan memanggil leluhur legenda penjaga alam itu atau leluhur. Melapor dengan penjaga nabi akar-akaran, pohonpohonan, dan rumput-rumputan. Doa memohon izin membuka lahan dari segi; (i) manusianya memohon selamat kepada para dewa-dewa atau leluhur, (ii) permohonan memperoleh beras benih yang baik, (iii) permohonan rizki.

\section{2) Pantangan Menebas Lahan}

Menebas lahan milik sendiri harus dilakukan dalam waktu satu hari, peladang memasang parang dan kayu di empat penjuru (empat persegi), yaitu menancapkan empat kayu di empat tempat bagian pojok dengan disertai bertanung dengan menancapkan pada kayu atau pakaian yang digunakan. Jika parang yang ditancapkan terlepas, tempat itu tidak direstui oleh leluhur untuk membuka tempat itu sebagai lahan berladang atau menanam padi dan tanaman lainnya.

\section{3) Pantangan pada saat Pembukaan Lahan}

a) Penebasan tidak boleh berhenti, b) penebasan dari hari pertama sampai ketiga tidak boleh berhenti (misalnya hari pertama turun, hari kedua tidak turun, dan hari ketiga turun), c) menegok ke belakang, dan d) jangan menegok kebelakang pada saat menebas/membuka lahan karena pekerjaan yang kita lakukan akan terasa lama (meluas perasaan/lambat selesai/ atau lilik dalam bahasa Dayak Halong).

\section{4) Pantangan Membuang Nasi}

Pantangan membuang nasi/jangan sampai basi karena dipercaya nasi tersebut menangis. Begitu juga dengan padi jangan sampai berhamburan karena diyakini padi-padi itu menangis (disia-siakan). Akibat dari pantangan tersebut apa yang dimakan kita tidak 
berkah dan tidak bermanfaat. Pantangan tersebut diajarkan orang tua kepada anak-anaknya sejak masih kecil. Setelah dipanen, bagi mereka yang memiliki adat sendiri harus melakukan ritual adat dulu. Penggunaan hasil panen yang baru sangat dipantang karena menurut masyarakat padi itu harus dimakan leluhur terlebih dahulu. Kita sangat disarankan menggunakan hasil panen tahun sebelumnya. Oleh karena itu, hasil panen yang baru tersebut harus dimamang atau dijampijampi diberi doa terlebih dahulu. Disampaikan kepada roh-roh atau dewa-dewa, setelah sampai pada mereka baru diperbolehkan memakannya. Jika kita melanggar pantangan itu, kita akan mengalami kesambetan/ kepuhunan. Saat ini yang sudah pindah agama, mereka tidak lagi menggunakan tradisi itu, sedangkan sebagian besar masyarakat masih melakukan tradisi adat sampai saat ini.

Larangan membuang antah (biji padi yang ada di dalam nasi) pada saat makan juga dilarang dalam tradisi kami. Seharusnya, antah itu dibuka terlebih dahulu, lalu isinya dimakan. Jika kita membuang antah itu, akan mengakibatkan antah itu menagis dan berakibat kualat (kemerostan moral, mental, dan ekonomi) kita.

Pantangan tidak boleh melanggar aturan, sedangkan larangan tidak boleh melakukan yang tidak dibenarkan. Konsep pantangan lebih khusus (menjiwai/penekanan), sedangkan larangan lebih umum. Posisi yang lebih di dalam masyarakat ialah pantangan. Ketika pantangan dilanggar, ada sangsinya dan karma berlaku, sedang- kan larangan bisa berlaku sesaat atau pada kesempatan tertentu saja.

Tidak boleh bersiul di dalam rumah karena akan mengalami kesambet atau kepuhunan. Dipercaya setiap rumah ada penghuninya, selain manusia. Jenis kesambet yang bisa terjadi misalnya sakit kepala, sakit gigi.

Pantangan kaget tumbung. Kaget tumbung ini tidak boleh dlakukan di dalam rumah karena akan berakibat kepuhunan juga. Jika ucapan tumbung ini diucapkan di lahan kita maka akan berakibat tanaman kita baik. Pantangan kaget tumbung. Kanget tumbung ini tidak boleh dlakukan di dalam rumah karena akan berakibat kepuhunan juga. Jika ucapan tumbung ini diucapkan di lahan kita maka akan berakibat tanaman kita baik. Pelarangan ke luar rumah menjelang senja/petang karena dikhawatirkan akan kesambet. Selain itu, pantangan lainnya berkata tidak senonoh pada tempat-tempat keramat karena mengakibatkan marahnya penunggu daerah tersebut.

\section{5) Pantangan Membakar Lahan Sebe- lum Pukul 4 Sore.}

Melaporkan kepada tetangga di pembatas api dan membakar lahan pada pukul 4 sore. Tujuannya pembakaran lahan pada pukul 4 sore itu karena anginya tidak kencang. Kalau membakar sekitar pukul dua siang, akan melibas keluar garis dan berakibat kebakaran. Hal ini terkait dengan toleransi dan mengikuti intruksi pemerintah larangan membakar lahan. Pentingnya memanggil tetangga dalam memberi pembatas suoaya kita tidak ketiwasan/tidak salah. Istilah kenyimaadah merupakan bacaan yang diarahkan 
untuk memadamkan api yang membakar lahan pembatas orang dengan cara diberi mantra.

\section{6) Pantangan Menancapkan Bamban Empat Persegi.}

Setelah membuka lahan, pepatah orang tua harus menancapkan bamban pada tempat empat persegi. Mengapa harus empat persegi, agar lahan kita tidak ditumbuhi rumput. Menurut kepercayaan orang tua karena di setiap penjuru itu ada yang menunggu/ menjaga. Kalau tidak dipenuhi aturan tersebut, lahan yang dibuka tersebut akan dipenuhi rumput. Pada dasarnya ada roh-roh leluhur yang ikut menabur benih-benih rumput lain yang mengakibatkan rumput di arena berladang mudah tumbuh subur.

\section{7) Pantangan Waktu Bercocok Tanam}

Setelah menebas lahan sampai bersih, untuk memulai penanaman harus melihat waktu yang tepat dulu. Waktu yang tepat itu diawali dengan munculnya anak wakat bertaburan di muka bumi. Sudah selayaknya benih padi itu ditanam (pada dasarnya melihat perbintangan terlebih dahulu). Anak wakat ini seperti belalang yang kecil-kecil yang berwarna hijau kemudian berubah menjadi coklat. Hal itu tanda-tanda menabur benih padi/bercocok tanam siap untuk dimulai.

Penanaman benih dimulai pada bulan Oktober dan November. Jika dilakukan lebih cepat dari yang dilakukan, maka padi akan diserang hama (hama nagau atau walang sangit) lebih banyak. Hal ini terjadi karena orang lain tidak melakukan apa yang dilakukan oleh kita sehingga menuju lahan yang sudah mulai duluan di buka. Pada saat penanaman benih padi, pembuka lahan juga harus mempertimbangkan iklim serta cuaca yang tepat. Oleh karena itu, pada bulan Oktober dan November, yaitu dianggap bulan yang cocok untuk bercocok tanam, termasuk menanam padi.

Pada saat permulaan penanaman semai padi hal yang perlu dilakukan, ialah membacakan mantra (membaca mantra bagi penduduk setempat sama artinya mereka memanjatkan doa kepada Tuhan melalui perantara lelhur nenek moyang mereka yang dianggap sebagai penunggu alam di sekitar tempat membuka lahan pertanian). Perlengkapan yang harus dipersiapkan, yaitu: a) bambu sepanjang satu meter yang dibentuk seperti pemandakan (tempat duduk), b) pasang buluh; yang awal arahkan ke barat dan di bagian atas tempatkan biji padi, c) sebelum memasang padi di atas, buluh/bambu. Kita harus membaca mantra/bakar kemenyan.

Pembacaan mantra ini dimaksudkan untuk kesiapan berlayar. Setelah mantra selesai dibacakan, barulah kita berpesan kepada bibit padi itu "dia akan berlayar dengan empat ranting untuk berlabuh". Maksudnya dia berlayar di laut dan suatu saat akan berlabuh di pulau sampai waktunya 5 bulan 5 hari perjalanan itu dari menyemai sampai jadi padi.

Padi itu diartikan emas dan intan. Kulitnya diartikan emas dan isinya dimaknai intan. Ranting padi itu digantung di tunggul di tempat sekitar area berladang. Setelah satu minggu kemudian diberdirikan kembali 
(ditegakkan). Pohon bambu itu dirobohkan kembali ke arah timur. Hal ini dapat dimaknai bahwa mereka telah mudik (pulang) atau kembali ke tempat kediaman. Perubahan arah dari barat ke timur ini setelah waktu tiga bulan (dulu berlabuh setelah mengarungi padinya kemudian kembali).

\section{8) Pantangan Makan Pisang di Tengah Ladang}

Proses berikutnya memilah-milah padi. Ada padi yang dituhankan atau padi yang akan dijadikan bibit berikutnya. Isi padi itu harus kencang dan padat. Setelah satu minggu, proses berikutnya ialah perawatan atau pemeliharaan. Dalam proses pemeliharaan, pembuka lahan dilarang makan pisang di tengah ladang, makan sambil berjalan, dan makan di atas batang. Jika melanggar pantangan tersebut, orang itu akan mendapat marabahaya seperti menyerupai monyet atau kera. Artinya, padi yang sudah tumbuh itu akan dimakan oleh monyet atau kera atau hama yang sejenisnya.

Setelah proses pemeliharaan, berikutnya memanen padi. Ada atraksi yang harus dilakukan, yaitu kita mengambil tangkai (biji padi itu untuk arah timur (matahari terbit) dan arah barat (matahari terbenam) dan ditambah lagi alam saudara. Jika kita tidak melakukan hal tersebut, maka mereka akan ikut menggerogoti hasil panen kita. Alam saudara terbagi menjadi saudara pokok terbagi empat (kaki satu, bayangan kita satu, saudara dewa, dan malaikat) ditambah empat satu saudara yang lain, datuk penunggu sebanyak tiga orang, anak Nabi Sulaiman Qorun (dia yang menjaga emas dan intan itu), menggaduh alam dunia (berkah yang ada akan dibagi lagi jangan sampai tertinggal), yaitu dibagi kepada roh pepohonan, kekayuan, dan lain-lain. Hal ini dilakukan agar padi yang didapatkan akan bertahan lama (mendapatkan berkah).

\section{9) Pantangan Melakukan Aktivitas Setelah Sehari Panen}

Setelah kita mengambil padi itu, kita diamkan selama satu hari agar tidak pamali. Setelah panen hari ini, besoknya tidak boleh melakukan aktivitas di ladang itu. Baru hari ketiga kita lanjutkan memanen kembali dengan catatan atau pantangan berikut: tidak boleh berbicara, tidak boleh menegadah muka ke atas, dan tidak boleh tegok kanan-kiri.

Sembilan wadah pengetaman pertama orang yang lagi panen tidak boleh berbicara dengan tujuan a) ntuk melepas biji padi dari tangkainya, kita harus membaca mantra. Angkat anjungnya yang sembilan tadi, kita ibuk lagi di atas api yang sudah di beri kemenyan. Tujuannya kita sambil berbicara dengan padi itu supaya tidak terkejut bahwa mereka sudah waktunya di panen, b) selesai itu, biji padi itu terbagi lagi diambil dari sembilan wadah tadi yang simpai di tikar, c) sebelum menjemur padi itu, kita letakkan parang, batu asahan (diamond) di bawah tikar itu supaya harakat, kuat, berkah padi itu, d) pengambilan padi pertama, harus ada beberapa daun dan mengisihkan 3 tangkai padi untuk disimpan selama-lamanya. Ketiga tangkai tersebut akan digunakan pada penanaman berikutnya sebagai bibit unggul. 


\section{0) Pantangan Pulang dari Rumah Orang Mati}

Pulang dari rumah orang meninggal tidak boleh pergi ke kebun atau ladang hari itu sampai besoknya. Hal ini dimaksudkan karena kondisi badan atau keadaan kita masih dalam kondisi kotor. Diharuskan kita dalam kondisi bersih, baru pergi ke ladang atau ke kebun pada hari berikutnya. Dari sisi toleransi bahwa masyarakat Dayak Halong sangat memperhatikan hubungan silaturahmi dan kekeluargaan. Pelanggaran terhadap pantangan tersebut mengakibatkan padi menjadi kuning, tidak berisi, tidak terurus, rusak, dan diserang hama. Akibat ini hanya berlaku untuk si pemilik lahan itu sendiri dan tidak berlaku kepada lahan orang lain.

\section{1) Pantangan Makan Tebu di Ladang}

Pantangan makan tebu) di kebun (apalagi sambil jalan) sangat dilarang. Akibat melanggar larangan tersebut berakibat padi kita dimakan tikus atau hama. Secara logika, makan sembarangan tempat tidak baik dalam masyarakat kita, alangkah baiknya kalau makan duduk yang baik sesuai aturan yang diatur dalam masyarakat itu.

\section{2) Pantangan Memasuki ke Tempat Orang Selesai Mambatur}

Orang yang selesai mambatur juga dilarang melintas di ladang atau memasuki di daerah ladang atau kebun (satu hari suntuk). Akibat dari melanggar pantangan ialah benih kita akan rusak walaupun diberi obat-obat penangkal rusaknya benih itu. Pelarangan itu sudah berlaku sejak nenek moyang mereka dari zaman dahulu. Saat ini, untuk generasi muda sudah tidak terlalu mengindahkan akan pantangan itu yang sudah dilakukan secara turuntemurun oleh orang tua mereka.

\section{3) Pantangan Menebang Melalui Mimpi}

Apabila mimpinya melihat wanyi berarti tidak dibolehkan membuka lahan karena akan berakibat berbahaya bagi orang itu. Wanyi dianggap oleh masyarakat adat Dayak Halong sebagai simbol binatang yang beracun apabila menyengat manusia dan dapat menyebabkan kematian apabila seseorang disengat wanyi (lebah), karena itu dalam pelarangan masyarakat apabila akan membukan lahan seseorang malam harinya melalui mimpi melihat wanyi dan akan membuka lahan untuk berladang kesokkan harinya, sebaiknya niat untuk membuka lahan tersebut, untuk dibatalkan dan merencanakan kembali waktu selain hari itu atau mengganti hari dan merencanakan ulang untuk membuka lahan. Tujuannya dengan tidak melanggar pantangan tadi seseorang dapat terhindar dari marabahaya yang akan terjadi di kemudian hari karena misalnya melanggar pantangan yang sudah mereka yakini bahwa apabila seseorang melanggar pantangan tersebut akan mendapatkan bahaya yang tidak terduga datangnya.

\section{PENUTUP}

Pantangan di dalam masyarakat dapat ditinjau secara umum dan lokal. Secara umum larangan merupakan suatu tindakan berdasarkan kepercayaan masyarakat tertentu. Larangan yang dimaksud sangat sakral untuk dilanggar karena tindakan tersebut terlalu berbahaya untuk dilakukan orang biasa. Pelanggaran terhadap pantangan itu 
bisa berakibat sakit, penderitaan, kesengsaraan, ketidakbahagiaan, bahkan berujung pada kematian. Aspek yang tersentuh oleh pantangan tersebut meliputi lingkungan sosial dan lingkungan pertanian, baik di ladang, kebun, maupun di sungai. Tujuan utama merupakan upaya pemeliharaan keseimbangan dan kelestarian hidup dan relasi sosial dengan alam (kearifan lokal). Kearifan lokal tersebut dapat ditanamkan dan diajarkan kepada generasi muda karena memiliki nilai sopan santun, etika. Upaya pemeliharaan lingkungan dan penghargaan terhadap makhluk gaib yang berdampingan dengan manusia.

Tinjauan lokal tentang pantangan dimaknai melanggar sesuatu akan terjadi sesuatu pula, ada ciri bahaya atau kurang baik, dan tidak menghasilkan, sedangkan melanggar dimaknai orangorang yang tidak memperhatikan pantangan yang ada di dalam masyarakat. Kedudukan pantangan ini bisa dikenai sanksi, sedangkan larangan tidak ada sanksi atau hanya sejenis teguran saja. Jadi, kedudukan pantangan sifatnya sangat kuat dan tajam (jelas), sedangkan larangan sifat lemah (sebaliknya).

Pantangan pada masyarakat Dayak Halong masih terjaga dan terpelihara dengan baik. Hal ini memiliki dampak positif terhadap masyarakat khususnya generasi muda. Dampak positif yang dapat ditimbulkan dari pelaksanaan pantangan dapat mengarahkan generasi muda lebih sopan, patuh, bertanggung jawab, dan memiliki etika terhadap lingkungannya. Pantangan yang bernilai kearifan lokal tersebut juga memberikan teladan bagi kita akan pentingnya menghargai ciptaan Tuhan dan menghormati para leluhur yang dipercaya oleh masyarakat adat turut menjaga kelangsungan alam ini.

Secara umum, masyarakat Dayak Halong masih menjaga pantangan yang mereka pahami sebagai bagian dari kearifan lokal. Mereka mempercayai kearifan lokal berupa pantangan itu sebagai warisan secara turun-temurun itu akan memberikan ciri, pertama sebagai wujud masyarakat adat (masyarakat yang menjaga tradisi leluhur). Kedua masyarakat Dayak Halong menjaga kemurnian adat leluhur yang merupakan bagian dari mempertahankan nilainilai kebudayaan leluhur yang dapat dipandang sebagai bagian kebudayaan nusantara. Ketiga keberadaan pantangan dalam masyarakat merupakan wujud adat istiadat yang mereka warisi dari nenek moyang mereka yang ada sejak dahulu.

\section{DAFTAR PUSTAKA}

Cassirer, Ernst. 1990. "Mitos dan Religi" dalam Manusia dan Kebudayaan: Sebuah Esei Tentang Manusia. Jakarta : PT Gramedia.

Daud, Alfani. 1997. Islam dan Masyarakat Banjar, Deskripsi dan Analisa Kebudayaan Banjar. Jakarta: PT Raja Grafindo Persada.

Danandjaja, James. 1997. Folklor Indonesia : Ilmu Gosip, Dongeng, dan lain-lain. Jakarta : Grafiti. 
Pantangan dalam Pembukaan Lahan Pertanian Masyarakat Dayak Halong (Saefuddin)

Dyson, Laurentius dkk. 2012. Sejarah dan Mitologi Suku Asli Kalimantan Timur. Surabaya : Citra Wacana.

Eliade, Mircea, 2011. "Myth and Reality", dalam A Reader in Classical Theory for the Study of Religions in Indonesia, Molume 3, ICRS-UGM: Yogyakarta.

Furchan, Arief. 1982. Pengantar Penelitian dalam Pendidikan. Surabaya: Usaha Nasional.

Harsojo. 1988. Pengantar Antropologi.Jakarta.https://idwikipedia.org/wiki/pantang.

Ibrahim.2012.Pantang Larang Masyarakat MelayuKabupaten Kapuas Hulu. Pontianak: Balai Pelestarian Nilai Budaya, Kalimantan Barat

Karsana, Deni. 2014. Mengungkap Fenomena Budaya Pantangan dalam Etnik Kili: Jendela Pemahaman Budaya Melalui Bahasa. Proceding "Fenomena Bahasa dalam Masyarakat Urban". Surabaya: Airlangga University Press.

Laksono, P.M. dkk. 2000. Perempuan di Hutan Mangrove: Kearifan Ekologis Masyarakat Papua.Yogyakarta : Galang Press.

Liliweri, Alo. 2014. Pengantar Studi Kebudayaan. Bandung : Nusa Media.

Naess, Arne dan Bob Jickling, "Deep Ecology and Education: A Conversation with Arne Næss", Canadian Journal of Environmental Education (CJEE), Vol 5, No 1 - 2000, http://cjee.lakeheadu.ca/index.php/ cjee/article/view/300.

Sartini, 2009. Mutiara Kearifan Lokal Nusantara. Kepel Press: Yogyakarta.

Sartini, 2009. “Kearifan Ekologis sebagai Implementasi Pandangan Organistik Holistik (Studi Kasus Masyarakat Hutan Adat Wonosadi Ngawen Gunung Kidul)", Laporan Penelitian, Fakultas Filsafat UGM: Yogyakarta.

Semi, M. Atar. 1990. Rancangan Pengajaran Bahasa dan Sastra Indonesia. Bandung: Angkasa.

Sisva, Maryadi. 2015. Mitos dan Pelestarian Lingkungan.Pontianak: Balai Pelestarian Nilai Budaya, Kalimantan Barat.

Stepanus, Ahadi Sulissusiawan. Pantang Larang Masyarakat Dayak Sungkung Kecamatan Siding Kabupaten Bengkayang (Suatu Kajian Sosiolinguistik), dalam http// jurnal.untan.ac.idindex.phpjpdpbarticleviewFile59806063 di akses 9 Februari 2016.

Tim Penyusun. 2013. Kamus Besar Bahasa Indonesia. Edisi Keempat. Pusat Bahasa. Departemen Pendidikan Nasional.

Van Peursen, CA. 1992. Strategi Kebudayaan. Yogyakarta : Kanisius. 